\title{
Social Differences in Preindustrial Demography: A Case Study on a Middle-sized Town
}

\author{
EINO JUTIKKALA
}

Academician

An important problem in the study of pre-industrial societies is whether social distinctions were manifested in demographic phenomena. A good opportunity to study this problem arises in those extremely rare cases where two or more congregations having an unlike social structure existed in the same geographic area. In Finland, there were two cases of this type, the cities of Turku and Viipuri. The differing demographic characteristics of the Finnish lower-class congregation, the mixed Swedish, and the upper-class German congregation in Viipuri have been dealth with by Turpeinen (1984). In the former capital, Turku, a Finnish and a Swedish congregation was in existence until 1845, when they were united and the keeping of separate parish registers no longer continued (Nikula, 1972, 398).

The social differences between the congregations in Turku were not as radical as in Viipuri. True, professional people and other officials spoke Swedish almost without exception. The lower burghers, who operated as cattle buyers, slaughterers, and tavern keepers, were traditionally called "Finnish burghers" in contrast to the Swedish merchants, and some grocers also belonged to the Finnish congregation (Nikula, 1970, 273-275, 280-287; Nikula, 1972, 398). According to the stables» compiled by the parsons in the year $1840,0.9 \%$ of the population of the Finnish congregation consisted of "persons of standing», $7.4 \%$ of burghers, and the great majority, $91.7 \%$, of common people. Consequently, the demographic characteristics of this congregation reflect those of the lower classes. In the Swedish congregation, the corresponding figures were $15.6 \%, 24.4 \%$, and $60.0 \%$; even if the lower classes were in a small majority, the middle and upper classes were proportionally five-fold greater than in the Finnish congregation. ${ }^{1}$ By the year 1870 , when the first census figures were published, the proportions had not essentially changed (taking into consideration that the classification may have been somewhat changed). Of the Finnish-speaking inhabitants of Turku $1.4 \%$ consisted of "persons of standing" including higher burghers, $33.0 \%$ of $»$ lower burghers and their equals», and the rest of common people, whereas $25.7 \%$ of the Swedish-speaking inhabitants consisted of persons of standing and $44.3 \%$ of lower burghers (Jutikkala, 1957, 403).

Unfortunately, comparisons between the two congregations can only be drawn for the years $1826-44$, since the earlier »tables» of the Swedish congregation seem to have disappeared.

The crude birth, death, and marriage rates in five-year average are given in Table 1 and the yearly variations in Figure 1 .

The crude birth rates were rather low for a pre-industrial town: the rate was below 30 per thousand in the Finnish congregation in 16 years (out of 19) and in the Swedish in 9 years. A partial explanation might be that the growth of the town had stagnated, the population totals being 13,609 in 1825 and 13,518 in 1845 . Obviously, there was no noticeable immigration of young couples. Stagnation and decline in middle-sized towns were no rarity in Europe during the pre-industrial period, ${ }^{2}$ and a terrible fire,

1 "Tables" in the parish record office of Turku where all primary sources quoted in this study are kept.

2 Particularly the matrices in tables 7.1.-7.9. (J. de Vries, 1984). 
$\mathrm{F}$ i g u r e 1. The crude birth, death and marriage rates in the Swedish and Finnish congregations of Turku 1826-1844.
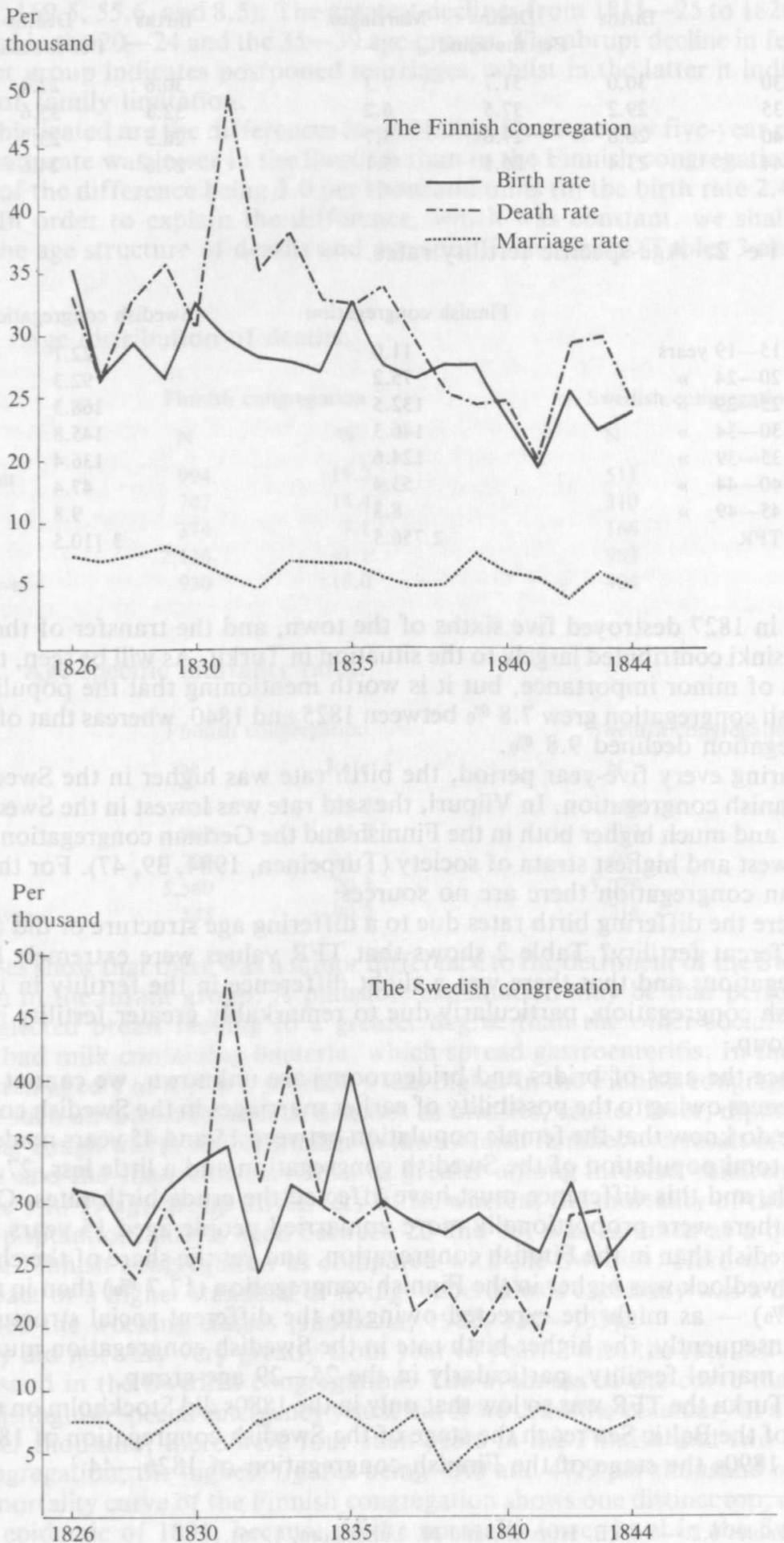
T a b l e 1. The crude birth, death, and marriage rates in five-year average.

Finnish congregation

Births Deaths Marriages

$\begin{array}{llll}1826-30 & 30.0 & 31.7 & 7.3 \\ 1831-35 & 29.2 & 37.5 & 6.2 \\ 1836-40 & 26.6 & 27.6 & 5.7 \\ 1841-44 & 23.4 & 26.5 & 5.1\end{array}$

$\mathrm{T}$ a b l e 2. Age-specific fertility rates.

Finnish congregation

$15-19$ years
$20-24 "$
$25-29 "$
$30-34 "$
$35-39 "$
$40-44 "$
$45-49 "$

TFR

11.0
75.2
132.5
146.3
124.6
53.4
8.3
756.5

2756.5
Swedish congregation

$\begin{array}{ccc}\text { Births } & \begin{array}{c}\text { Deaths } \\ \text { Per thousand }\end{array} & \text { Marriages } \\ 30.6 & 27.4 & 7.4 \\ 32.3 & 35.6 & 7.9 \\ 28.5 & 23.7 & 6.2 \\ 27.6 & 24.6 & 7.8\end{array}$

which in 1827 destroyed five sixths of the town, and the transfer of the University to Helsinki contributed largely to the situation in Turku. As will be seen, this explanation is of minor importance, but it is worth mentioning that the population of the Swedish congregation grew $7.8 \%$ between 1825 and 1840 , whereas that of the Finnish congregation declined $9.8 \%$.

During every five-year period, the birth rate was higher in the Swedish than in the Finnish congregation. In Viipuri, the said rate was lowest in the Swedish congregation and much higher both in the Finnish and the German congregation, i.e. among the lowest and highest strata of society (Turpeinen, 1984, 39, 47). For the Orthodox Russian congregation there are no sources.

Were the differing birth rates due to a differing age structure or did they depend on different fertility? Table 2 shows that TFR values were extremely low in both congregations and that there was a slight difference in the fertility in favor of the Swedish congregation, particularly due to remarkably greater fertility in the $2-29$ age group.

Since the ages of brides and bridegrooms are unknown, we cannot explain the differences owing to the possibility of earlier marriages in the Swedish congregation. But we do know that the female population between 15 and 45 years made up $29.4 \%$ of the total population of the Swedish congregation and a little less, $27.2 \%$, in the Finnish, and this difference must have affected the crude birth rates. On the other hand, there were proportionally more unmarried people aged 15 years and over in the Swedish than in the Finnish congregation, and yet the share of the children born out of wedlock was higher in the Finnish congregation $(17.7 \%)$ than in the Swedish $(14.6 \%)$ - as might be expected owing to the different social structure.

Consequently, the higher birth rate in the Swedish congregation must be due to higher marital fertility, particularly in the $25-29$ age-group.

In Turku the TFR was so low that only in the 1880 s did Stockholm on the opposite shore of the Baltic Sea reach the stage of the Swedish congregation of 1826-44 and in the 1890 s the stage of the Finnish congregation of $1826-44 .^{3}$

${ }_{3}$ Tables 6.2.-6.6. (E. Hofsten, and H. Lundström, 1976). 
In order to find out whether this extremely low fertility dates from olden times or was an innovation, I have calculated the TFR for the years $1811-25$ in the Finnish congregation - it cannot be calculated for the Swedish congregation. The estimations resulted in a remarkably higher figure, 3410.5 (for the different age groups $15.9,117.8$, $160.9,153.9,169.5,55.6$, and 8.5). The greatest declines from $1811-25$ to $1826-44$ were observed in the $20-24$ and the $35-39$ age-groups. The abrupt decline in fertility in the former group indicates postponed marriages, whilst in the latter it indicated some form of family limitation.

Less sophisticated are the differences in mortality. During every five-year period the crude death rate was lower in the Swedish than in the Finnish congregation, the mean value of the difference being 3.0 per thousand units (in the birth rate 2.45 per thousand). In order to explain the difference, which was constant, we shall first investigate the age structure of deaths and age-specific mortality (Tables 3 and 4).

$\mathrm{T}$ a b l e 3. Age distribution of deaths.

\begin{tabular}{lcccc} 
& \multicolumn{2}{c}{ Finnish congregation } & \multicolumn{2}{c}{ Swedish congregation } \\
& $\mathrm{N}$ & $\%$ & $\mathrm{~N}$ & $\%$ \\
Less than 1 year & 994 & 19.2 & 511 & 22.3 \\
$1-4$ years & 747 & 14.4 & 310 & 13.5 \\
$5-19$ years & 374 & 7.1 & 166 & 7.2 \\
$20-59$ years & 2,126 & 41.1 & 903 & 39.4 \\
60 years and over & 930 & 18.0 & 404 & 17.6
\end{tabular}

T a b l e 4. Age-specific mortality rates.

\begin{tabular}{lrrrr} 
& \multicolumn{2}{c}{ Finnish congregation } & \multicolumn{2}{c}{ Swedish congregation } \\
& N & Rate & N & Rate \\
Less than 1 year & 256 & 203.7 & 115 & 234.7 \\
1-4 years & 702 & 55.5 & 379 & 42.2 \\
$5-19$ years & 1,709 & 11.7 & 697 & 12.9 \\
20-59 years & 5,580 & 20.1 & 3,078 & 15.3 \\
60 years and over & 543 & 90.2 & 218 & 96.3
\end{tabular}

Both tables show that there was a minor difference to the detriment of the Swedish congregation in the infant group. A plausible explanation may be that persons of standing neglected breast feeding to a greater degree than the other social strata and bought bad milk containing bacteria, which spread gastroenteritis. In the next group, children aged 1 to 4 years, mortality was higher in the Finnish congregation. Exposure to such air-borne infectious diseases as measles, scarlet fever, diphtheria, and whooping-cough was probably smaller in the Swedish families as a result of better nourishment and the chance of survival was greater among infected children. The figures in the 5 to 19 age-group differ very little, whereas the mortality of the great bulk of the population, adults aged between 20 and 59, was as much as a quarter higher in the Finnish congregation as compared with the Swedish. Here we surely find the impact of a higher standard of living; tuberculosis especially was a disease that throubled the working classes (Jaakkola, 1982, 154-159).

Mortality did not vary very greatly from year to year. Twice the rate fell below 20 per thousand in the Swedish congregation. The evenness of the curve makes it difficult to distinguish special emergency years, but if we draw the boundary at a death rate of 35 per thousand, there were four such years in the Finnish and two in the Swedish congregation, the highest figures being 49.0 and 47.9 per thousand respectively. The mortality curve of the Finnish congregation shows one distinct top, during the cholera epidemic of 1831 ; because of the normally lower level in the Swedish 
congregation there was another top in its curve during the smallpox epidemic of 1833 . During the years of high mortality, there was no top in the share of the $1-4$ agegroup in total mortality, a top that I have observed in the surrounding countryside during the period 1750-1850 (Jutikkala and Kauppinen, 1971). To a great degree, the evenness is due to the fact that smallpox ceased to be a regularly occurring epidemic. Hundreds of children were vaccinated in almost all those years this action was reported in the sources. Turku was only hit by one smallpox epidemic, which lasted more than one year (from October 1832 to October 1833), and even this epidemic was not very severe: it claimed 114 victims. True, this disease was still endemic and killed some children virtually every year. Other lethal contagious diseases were whooping-cough, measles, scarlet fever, dysentery, and »nerve and rot fever», which may have referred to some kind of typhoid disease. Perhaps "gastric fever» ought to be included as well, but in its case the diagnosis is rather suspect, it only being reported in the Finnish congregation - and even then for no more than five consecutive years - and it is impossible that this food-borne disease would not have spread from the Finnish-speaking families to the Swedish-speaking ones.

Mean mortality for all contagious diseases in the Finnish congregation was 4.8 per thousand, and in the Swedish 3.8. There was a distinct difference to the former's disadvantage, and the ratio grows in the former to 5.2 if the "gastric fever» is included. Since total mortality rates (weighed mean values) were 29.7 per thousand and 26.5 respectively, the contagious diseases do explain a certain part of this difference, but at most two fifths only. In Viipuri, mortality was much higher in the Finnish than in the Swedish and German congregations, and so was infant mortality. Dysentery, measles, whooping-cough, and smallpox took a much heavier toll among the lower than the higher classes, whereas with scarlet fever its was the opposite (Turpeinen, 1984, 42-44).

The worst demographic crisis was caused by a cholera epidemic which raged from September 1831 to January 1832 . Cholera is regarded as a socially selective disease, and so thought the contemporary Finns. When the next epidemic arrived in Helsinki in 1853, the University Librarian, S. G. Elmgren, wrote on his diary: "Hitherto it has been members of the working class only who have perished, and therefore the educated classes take the situation fairly easily. $n^{4}$ Actually, in Turku cholera killed 159 persons (17.7 per thousand) in the Finnish and 53 (12.7 per thousand) in the Swedish congregation. Consequently, there was a remarkable difference in the exposure, but even in regard to this disease no categoric conclusions can be drawn, for among those who died were a considerable number of persons of standing including the one of the two burgomasters (Nikula, 1972, 238). Cholera was particularly dangerous for old people: no less than 129 of its victims were aged 50 or over, whereas only 13 children under 10 years died.

If the demographic characteristics of the middle and upper classes - e.g. as a result of better nourishment and hygiene - differed from those of the lower classes, they ought to appear as differences in the demographic traces of the Finnish and Swedish congregations in Turku. Such differences have been found, particularly in the mortality of the adult population, but they are not very marked.

\section{References}

De Vries, J. (1984). European Urbanization, 1500-1800. Harvard Studies on Urban History. Cambridge, Mass.: Harvard University Press.

Hofsten, E.; and Lundström, H. (1976). Swedish Population History. Main Trends from 1750-1970. Stockholm, Sweden: Statistiska Centralbyrån.

${ }^{4}$ S. G. Elmgrenin muistiinpanot (Notes of S. G. Elmgren), p. 66. Cf. p. 69 where Elmgren describes a concert and a ball which were arranged heedless of infection by the upper classes in order to afford relief for the cholera ridden families in the lower classes. 
Jaakkola, J. (1982). Työväestö ja sosiaalinen poikkeavuus. (Workers and social deviation). A licentiate work. Tampere, Finland: University of Tampere, Department of History. (The study deals with Tampere).

Jutikkala, E. (1957). Turun kaupungin historia 1856-1917. (History of the city of Turku 1856-1917). Turku, Finland: Turun kaupunki.

Jutikkala, E.; and Kauppinen, M. (1971). The structure of mortality during catastrophic years in a preindustrial society. Population Studies (London, England) 25(2): 283-285.

Nikula, O. (1970). Turun kaupungin historia 1721-1809. (History of the city of Turku 1721-1809). Turku, Finland: Turun kaupunki.

Nikula, O. (1972). Turun kaupungin historia 1809-1856 (History of the city of Turku 1809-1856). Turku, Finland: Turun kaupunki.

S. G. Elmgrenin muistiinpanot (1939). (Notes of S. G. Elmgren, published and translated into Finnish by A. Maliniemi).

Turpeinen, O. (1984). Befolkningsförhållandena i Viborgs finska, svenska och tyska församlingar åren 1816-1865. (Demographic characteristics of the Finnish, Swedish and German congregations in Viipuri in 1816-1865). In Svenskt i Finland 2: Demografiska och socialhistoriska studier, edited by Max Engman and Henrik Stenius, pp. 37-51. Skrifter utgivna av Svenska litteratursällskapet i Finland, nr 519. Helsingfors, Finland: Svenska litteratursällskapet i Finland.

\section{Some remarks on the tables}

The population totals of the congregations are reported every five years only. In all figures illustrating the structure of population, mean values for the years $1825,1830,1835$, and 1840 have been used. The early birth, death, and marriage rates have been calculated supposing that the increase - or decrease - of the population has been equally divided between the five years in question. It has been assumed that the shares of the Finnish-speaking and Swedish-speaking population of the population totals were the same in 1845 as in 1840 .

Totally exact figures for age-specific fertility cannot be calculated, because the source material giving the age of mothers does not give the number of children they delivered but instead it gives the number of deliveries. Fortunately, the two small biases caused by this inconvenience counterbalance each other: stillbirths are included in the number of births, on the other hand twins are reported as if there were one child only. 